Arhe XVII, 33/2020

UDK 141.8 Pannekoek A.

DOI https://doi.org/10.19090/arhe.2020.33.27-63

Originalni naučni rad

Original Scientific Article

\author{
LEV KREFT $^{1}$ \\ Univerzitet u Ljubljani, Filozofski fakultet, Slovenija
}

\title{
KAKO JE PANEKUK TRI PUTA POSTAO OTPADNIK
}

Sažetak: Cilj istraživanja bio je proučavanje Panekukove delatnosti i tekstova kao izvora obaveštenja o kretanju kroz istoriju revolucionarnog pokreta i marksističke teorije. U ovom članku to je kretanje svedeno na tri raskola: između revizionizma i ortodoksije, između reformizma i revolucije, i između državnog komunizma i komunizma saveta. Time smo ostavili sa strane prvi sukob između anarhizma i Marksa odnosno marksizma, jer su anarhisti prvi isključeni, pa taj raskol Panekuk nije obilato komentirao. Zaključak je da raskol između državnog komunizma i komunizma saveta jeste izgubljena karika podele na zapadni i istočni marksizam koja izvire iz sukoba oko strategije i taktike u komunističkoj Internacionali (1920-1922) sve dok se nije u Levičarstvu - Dečjoj bolesti komunizma učvrstio Lenjinov strateški i taktički pravac protiv svih koji su se protivili parlamentarnoj i sindikalnoj strategiji kao jedinom komunističkom revolucionarnom angažmanu. Panekuk se protivio tom ishodu sav svoj preostali teoretski i aktivistički život. Najvišu moguću tačku razumevanja sa svoje tačke gledišta postigao je u knjigama Lenjin kao filozof (1938) i Radnički saveti (1941-1947). Kada je na kraju uspostavio kontakt sa grupom Socijalizam ili varvarstvo Kornelijusa Kastorijadisa i Kloda Lefora 1953. godine, objasnio je svoje gledište novim generacijama revolucionara i marksističkih teoretičara kroz dopisivanje sa Kornelisuom Kastorijadisom. Konflikt i njegove razorne posledice daleko su od toga da pripadaju prošlosti. U naše vreme, označeno sa raznih strana kao prelazak u postkapitalizam, on se javlja ponovo, ovaj put na globalnoj razini.

Ključne reči: Anton Panekuk, zapadni marksizam, radnički saveti, nova klasa, Lenjinov vulgarni materijalizam

Najveći deo korpusa zvanog marksizam sastoji se od igre citata. $\mathrm{Ne}$ radi se tu o interpretacionom cepidlačenju (makar ga obilato nalazili u celokupnoj istoriji marksizma) već o presađivanju kose proizvedene u

\footnotetext{
${ }^{1}$ E-mail adresa autora: lev.kreft@ @ff.uni-lj.si
} 
teorijama na ćelavu glavu revolucionarne prakse u nadi da će se bar tu i tamo jedna od dlaka prihvatiti. Na početku, u Prvoj internacionali, o marksizmu se još ne može govoriti na neki ubedljiv način, jer su Marks i Engels sami bili arbitri o vlastitim idejama i usmerenjima, a prva je Internacionala (1864-1876. odnosno 1881.) bila scena sukoba između više doktrina i strategija radničkog objedinjavanja: komunizma Marksa i Engelsa, bakunjinovskog anarhizma, blankizma, prudonizma, a u Nemačkoj i sa lasalovcima. Glavna dva aktera, Bakunjin i Marks, nisu bili sposobni da povuku značajniju većinu na svoju stranu niti su mogli da održe savezništvo, te se zbog toga savez raspao na dva dela. Iza tih događaja neprestano je strujala korespondencija između Marksa i Engelsa sa Vilhelmom Libknehtom, Zorgeom, Dicgenom, Beblom i drugim nemačkim drugovima. U toj korespondenciji se korak po korak stvarao „marksizam“, da bi se nadovezivanje između marksističke teorije i revolucionarne prakse desilo tek u Drugoj internacionali (1889 - 1916). I ta je Internacionala bila polje sukoba, ne manje intenzivnih i destruktivnih kao u Prvoj internacionali, samo što su se razmimoilaženja sada izražavala u sukobima između suprotstavljenih marksističkih ortodoksija revizija marksizma. I ta je Internacionala propala, i to na sudbonosniji način od prve jer je sve do početka prvog svetskog rata obećavala da će sprečiti rat, da bi onda stala zajedno sa svim drugim šovinistima u prve redove militarizma. Malo je bilo izuzetaka: Lenjinovi boljševici, Tucovićeva srpska socijalna demokratija, deo bugarske stranke, pa i Karl Libkneht, Klara Cetkin i Roza Luksemburg. I, ne zaboravilo se, protiv rata se izjasnio i „revizionist“ Edvard Bernštajn. Parlamentarnim glasanjem poslata je poruka „moji su mi buržuji bliži od stranog radništva" koja je značila da je Druga internacionala proglašena poraženom stranom već na samom početku svetskog sukoba. Katastrofa se odvila tokom rata i odmah posle njega. Pokret koji je pre rata izgledao opasno jak, posebno u Nemačkoj, raspao se na drugu, drugu i po, pa treću, samo malo kasnije i na četvrtu Internacionalu...sve do kraja svih internacionala. Time nije nestala samo internacionalna solidarnost radništva. Raspala se veza između marksističke teorije i revolucionarne prakse. Razdoblje formiranja marksističkih ortodoksija, katastrofe proleterskog internacionalizma i kraja povezanosti između 
revolucionarne teorije i prakse jeste doba kojem pripada Anton Panekuk $(1873-1960)$.

\section{GDE JE ANTONU PANEKUKU MESTO?}

Izvori istorije marksizma Panekuka ili ne spominju ili se pojavljuje kao pristalica „komunizma saveta“. Ako su oznake za koju rečenicu produžene, okarakterisan je kao adresat Lenjinove kritike dečje bolesti levičarstva. Odakle potiskivanje na marginu i potpuno nestajanje ličnosti koja je za vreme života imala vidljivo mesto i priznatu misaonu težinu? Zašto potiskivanje autora koji je objedinjavao ulogu vrhunskog astrofizičara sa angažmanom komuniste i teorijskom delatnošću marksiste? Zbog unutrašnje logike marksizma na prvom mestu je nemogućnost prisvajanja. U istorijsko materijalističkoj istoriji marksizma, kakve još nema, glavnu bi ulogu imala tačka centralne moći koju drži ortodoksija. Radi se o odnosima institucionalizovane moći čije linije određuju šta važi za marksizam, da bi se u odnosu na njih onda odredile i pozicije revizionizma, reformizma, dečjih bolesti, renegatstva, izdajstva i sličnih centrifugalnih pojava. Zbog logike koja se ispoljava kroz istoriju marksizma za savremenu naraciju te istorije potrebno je polaziti od identifikacije centara moći umesto od traženja pravilne interpretacije.

\section{BIOGRAFIJA}

Antonie - Anton Panekuk rodio se 1871. godine u holandskom Vasenu. Astronomija ga je odmalena privlačila. Članak o promenljivosti zvezde Severnjače objavio je pre nego se upisao na studije matematike i fizike u Lejdenu, da bi se kasnije posvetio raspoređenosti zvezda u našoj galaksiji (Mlečnom putu), čime u Holandiji počinje shvatanje astrofizike kao samostalne nauke. Nekoliko godina posle završetka studija zaposlio se u lejdenskom opservatoriju i tamo dovršio doktorsku disertaciju. Već i onako u zategnutim odnosima sa konzervativnom naučnom okolinom zbog inovativnog stava u astronomiji, dodao je i skandaloznu poslednju kap kada ga je čitanje Jednakosti Edvarda Belamija (Belami, 2007) 
opredelilo za socijalizam i usmerilo ka sistematskom proučavanju radova Marksa, Engelsa i Dicgena. Pošto to nije krio i angažovao se odmah u radničkom štrajku, na opservatoriju su ga suočili za izborom: ili socijalizam ili opservatorij? Odabrao je socijalizam i otišao u Berlin gde su mu na preporuku Kautskog dali mesto predavača u socijademokratskoj partijskoj školi. Radikalni stavovi i tu su prouzrokovali sukob i sa vladinim krugovima i sa sindikatima, pa je bio prisiljen da pređe u slobodne pisce i predavače. Početak Prvog svetskog rata zatekao ga je u Holandiji odakle se nije mogao vratiti u Berlin. Prvo se zaposlio kao učitelj, da bi od 1916. godine bio opet u Lejdenu, ovaj put kao privatni docent. Iz krugova oko holandske vlade čuli su se prigovori zbog njegovih političkih stavova, ali ga je amsterdamski gradski savet zaposlio na univerzitetu usprkos tome, pa je napravio lepu karijeru sve do redovnog profesora (1932) i direktora opservatorija koji danas nosi njegovo ime. Nastavio je da se bavi distribucijom zvezda i strukturom galaksija, pa i pitanjima prirode i evolucije zvezda. Za vreme drugog svetskog rata kada neko drugo istraživanje nije bilo moguće posvetio se istoriji astronomije. Njegova Istorija astronomije održala se kao referenca sve do danas. Njezina je karakteristika stavljanje duge istorije astronomije u kontekst ekonomskih i društvenih prilika i njihovih promena od prapočetaka do najnovijeg vremena. (Pannekoek, 1961) Njegovo ime nose krater na Mesecu i asteroid 2378.

U isto vreme pored izuzetne naučne karijere učestvovao je u svim velikim sukobima radničkog pokreta u bitnom periodu, od konflikta o revizionizmu koji se rasplamsao na prelasku iz devetnaestog u dvadeseti vek, do nastajanja novolevičarskih pokreta na početku šezdesetih godina prošlog veka. Njegova su se shvatanja menjala i razvijala upravo u tim sukobima, usred radničkog pokreta u kome je neprestano zauzimao mesto radikalne levice, bila to levica Druge internacionale, cimervaldska levica u toku Prvog svetskog rata, ili u vreme prvih levičarskih kritika ruske revolucije zajedno sa Rozom Luksemburg i Karlom Koršem. Na početku aktivističkog puta pripadao je holandskom socijalno demokratskom savezu Domele Nivenhujsa koja se bez obzira na svoje neslaganje sa njima protivila isključivanju anarhista iz internacionale. Tu bi trebalo da postanemo oprezniji, jer su se oko zauzimanja mesta unutar 
internacionale i radničkog pokreta, kao i unutar marksizma, nagomilali nimalo nedužni izrazi, koji su napravljeni za uzdizanje i osuđivanje, zavisi od toga, ko ih izgovara: anarhizam, anarhosindikalizam, revizionizam, ortodoksija, reformizam, dijamat, levičarenje... Istorija marksizma jeste gomila označitelja koji sami po sebi čine ono što označavaju: guraju ljude, pokrete i pojave na svoje mesto u celini marksizma. U tom je postupku najznačajnije shvatiti sa kog se uporišta ta distribucija marksističkih pojava napinje da nam naturi svoju sliku ideološke vaseljene. Poziciju sa koje se izgovaraju te oznake razotkriva u prvom redu naboj prihvatanja ili odbacivanja označenih investiran $u$ regrutiranje piona na šahovskoj dasci na kojoj (kao u Benjaminovoj alegoriji) uvek pobeđuje lutak kome upravlja skriveni patuljak. U tim odnosima moći Panekuk je uvek bio negde na rubu, više puta izbacivan ili je sam otišao da bi na kraju ostao u vezi samo sa malobrojnim komunistima saveta (council communists). Bez obzira na sve to bio je do kraja Prvog svetskog rata i prvih godina posle njega jedan od najuticajnijih aktivista socijalne demokratije. Njegov i njegovih drugova i drugarica put na marginu stvarno je počeo tek posle razdoblja nastajanja novih kontura razjedinjenog međunarodnog radničkog pokreta iz razdoblja 1920-1922. kada je diskusija o revolucionarnoj strategiji i taktici postigla vrh i prelomnu tačku.

O čemu se radilo, gde i kada se desilo razdvajanje čiji je ishod bio ponor između socijalno demokratskih i komunističkih pokreta i stranaka, prilično je poznato istraživačima istorije radničkog pokreta $\mathrm{i}$ revolucionarnih zbivanja dvadesetog veka. Mnogo je manja pažnja posvećena onima koji se ne mogu svrstati. I upravo tu je mesto Antona Panekuka koji se održavao u toj poziciji nepripadanja punih četrdeset godina, i smatrao svojim zadatkom u revolucionarnoj teoriji - kako misliti tu sudbinsku pocepanost na dva dela od kojih ni jedan ne može da predstavlja spoj između revolucionarne teorije i revolucionarne prakse? Tom ćemo se procesu raspadanja približiti u tri koraka. U sva tri Panekuk je igrao aktivnu, čak aktivističku ulogu, ali i ulogu teoretičara marksizma. Prvi je korak sukob o revizionizmu ili o kontinuitetu revolucionarne teorije i prakse. Drugi je korak zaoštravanje oko reforme i/ili revolucije. Treći je korak sudbonosno razmimoilaženje o ulozi Partije i Države u 
revolucionarnom procesu. Ti koraci obuhvataju period od pre Prvog svetskog rata do vremena odmah posle njega kada je revolucija u isti mah pobedila (u Rusiji) i bila poražena (na Zapadu). Pored tog vremenskog okvira ta su tri koraka ono što se ponavlja u raznim periodima i situacijama različitih pokreta i organizacija za ukidanje kapitalizma kao neprestano se ponavljajuće dileme:

- Koje nasledstvo iz prtljaga tradicije, posebno iz Marksa, pokazuje put kojim treba krenuti - ako uopšte takvo nešto postoji?

- Da li se kapitalizam može preokrenuti reformama, čak i promenama kojima će se poslužiti samim sobom, ili je jedini put masovni ustanak, pobuna, revolucija?

- Da li se prevrat može sprovesti samo tako, da mase povede i njima rukovodi elitna grupa partijskih rukovodilaca koja će stvoriti novo uređenje upotrebom državnog aparata koji posle treba baciti u starudiju, ili je revolucija socijalni proces koji sam iz sebe, iz same akcije masa svaki put nanovo pronalazi sam sebe?

\section{SUKOB O REVIZIONIZMU}

Istorija marksizma ne oskudeva u sukobima oko revizionizma jer je „revizionizam“ postala opšta oznaka za razne načine skretanja i izdaje pravilnog smera radničkog pokreta, kao i za sve moguće načine opuštenijih odnosa prema Marksovom delu. To je bilo moguće jer je Marksovo igralo ulogu koju u Aristotela ima prvi nepokretni pokretač (proton kinun akineton). Edvard Bernštajn ostaje onaj kojim se uspostavlja simbolička ideološka tačka. Dva su razloga najznačajnija. Bernštajn, pod jedan, nije prouzrokovao vihor neodobravanja zbog toga jer je tvrdio da pojedine naučne istine i predskazanja Karla Marksa niti su tačne niti su se ispunile. On je doista negirao nekolicinu takvih činjenica i dirnuo $\mathrm{u}$ one momente koji su pucali po šavovima od očekivanja konačnog spasenja. Bernštajn je naprotiv tvrdio da kapitalizam nije društveno uređenje koje će zbog vlastitih protivrečnosti pokopati samoga 
sebe, pa i čovečanstvo, ukoliko to ne spreči proleterska revolucija. Kapitalizam (ekonomija kapitala i parlamentarna demokratija) je, kako kaže Bernštajn, uređenje koje će postojati duže vreme - možda će se reformama preokrenuti u socijalizam, a možda i neće. Tome se usprotivila velika koalicija, ali ga nisu isključili iz Internacionale kao što su to uradili sa anarhistima. Drugi razlog za mitologizaciju Bernštajna kao marksističkog Efijalta nalazi se u značenju kakvo je najavljivanje proleterske revolucije imalo za dve inače (a to se odmah posle sukoba oko revizionizma i pokazalo) nespojive grupe socijaldemokrata i marksista u Drugoj internacionali. Socijaldemokratski centar sve je vreme bio pod pritiskom i s mukom je održavao centralno mesto. Za njega sukob sa revizionizmom koji je stavljao revoluciju u drugi plan a reformu u prvi nije bio nužan zbog toga što bi oni stavljali revoluciju u prvi plan svoje strategije. Naprotiv, revolucije su se plašili, ali im je ujedno bio potreban strah buržoazije od socijalne demokratije da bi bili dovoljno značajni u pravljenju računica i koalicija za vlast sa tom istom buržoazijom. Odbacivanjem Bernštajna prigrlili su mogućnost da se neobaveznim prihvatanjem revolucije stave u ulogu ortodoksije koja čuva Marksovu izvornu poruku, i u ulogu centra političke snage koji pretvara socijalne pretnje revolucijom u reforme postojećeg poretka koje buržoaske stranke nisu sposobne izvesti. Radikalna levica odbacila je revizionizam zbog toga što je za nju revolucija bila jedini strateški odabir: socijalnu demokratiju treba stvoriti kao ozbiljnu snagu, ali ne zbog pobede na izborima već zbog toga šta njena pobeda znači totalni preokret društvenog uređenja. Radikalna levica bila je manjina unutar Internacionale, ali manjina koja je dosta doprinela da se socijaldemokratski centar formira kao ortodoksija, jer je i sama upotrebljavala argumentaciju prosvećene manjine sledbenika - ortodoksa.

U te i druge frakcijske borbe Panekuk je, još uvek sav zelen, upao odmah. Kada su izašle Bernštajnove Pretpostavke socijalizma (Bernštajn, 1993; prvo izdanje 1899.) on je tek pristupio holandskoj Socijalno demokratskoj radničkoj partiji (SDAP), čak se na lokalnim izborima te iste godine još našao na listi liberala. U liberalnim krugovima bio se zainteresovao za ideje kojima bi mogle promeniti svet na bolje. Panekuk je bio sistematičan i u takvim naivnim interesovanjima, pa je počeo da 
čita sve na što je naišao, jedan plan poboljšanja sveta za drugim - a kraj devetnaestog veka time svakako nije oskudevao. Tako je stigao i do drugog utopijskog romana Edvarda Belamija Jednakost (prvi je bio Pogled unatrag iz 2000. u 1887. godinu) koji je bio upravo izašao (Belami 1903, prvo izdanje 1897)), i to u vreme kada je Belami bio značajna ličnost u levičarskom političkom pokretu u SAD. ${ }^{2}$ Lejden nije bilo idealno mesto za početak socijaldemokratskog aktivizma jer je tamo i pokret bio na samom početku. Panekuk je rovite okolnosti prihvatio kao poticaj. Organizovao je koordinaciju svih radničkih organizacija i proučavao društvene nauke i humanističku literaturu uključujući Marksa, Engelsa i socijaldemokratske marksiste. Sve što je proučio prenosio je socijaldemokratskoj i radničkoj publici iz glave u usta. Opredelio se za osnivanje zadruga, pa je kumovao i otvaranju radničke pekare kojoj je dao finansijski doprinos te posle rada u opservatoriji dolazio da mesi i peče hleb. Za mladog vrhunskog intelektualca to je moralo biti i te kako uzbudljivo razdoblje. Za vreme studija otkrio je i radove Jozefa Dicgena kome je Marks tepao da je „naš filozof“. Panekuku kao čoveku prirodnih nauka bio je zanimljiv Dicgenov dijalektički materijalizam kojim je objašnjavao nastajanje i delovanja uma i mozga. (Dicgen, 1958) Te iste 1899. godine počela je s izlaženjem revija De Nieuwe Tijd (naslov naravno prevodi nemački Die Neue Zeit) čije je uredništvo bilo sastavljeno od intelektualaca učlanjenih u SDAP. Panekuka su odmah pozvali da im se priključi. U 1901. godištu u tri je nastavka objavio studiju Kantova filozofija $i$ marksizam. Uz uvođenje Dicgenovog dijalektičkog materijalizma i Hegelovog metoda u središte je stavio kritiku neokantovske filozofije. Time je ušao u filozofsko jezgro konflikta, jer su revizionisti tražili da se sa Marksa na Hegelovoj podlozi pređe natrag ka Kantovom kriticizmu. Panekuk se usprotivio. Što se Marksa tiče, njegov je argument bio da Marks nije ponudio materijalističku verziju scijentističkog pozitivizma, nego se kod njega

\footnotetext{
${ }^{2}$ Već je Pogled unatrag prouzrokovao nastanak stranke nacionalista koja nije odgovarala današnjem pojmu nacionalizma nego se borila za nacionalizaciju velikih kapitala, preduzeća i korporacija. Jednakost prikazuje kako deluje društvo zasnovano na egalitarnosti vlasništva i prava, i objašnjava kako je do promene iz društva zasnovanog na profitu do egalitarnog društva došlo mirnim putem.
} 
radi o istorijsko materijalističkoj nauci koja je okrenuta praksi. Što se Kanta tiče njegov je argument bio da Kantova etika nije prikladna za socijaldemokratsku praksu. Time je odredio filozofsko - ideološko mesto na kome je radio i razvijao ga i kasnije. Tako brzo zauzimanje može se objasniti njegovim opredeljenjem u nauci, gde je kao astronom pripadao novoj generaciji naučnika koja u nauci nije videla metod kojim se dopire do apsolutnog saznanja već način izrade teoretičkih modela koji, ma kako bili napredni u odnosu na dojučerašnje modele, uvek ostaju samo delimični vidici istine i realnosti. Panekuka je ta njegova verzija marksizma naoštrena protiv pozitivizma i scijentizma prvo dovela do odbijanja Engelsovog tročlanog dijalektičkog metoda (prelazak sa kvantiteta na kvalitet, jedinstvo suprotnosti, negacija negacije), a kasnije do oštre kritike Lenjinovog Materijalizma i empiriokriticizma. Što se etike tiče, Panekuk se u svojoj prvoj marksističkoj objavi slaže sa Bernštajnom o potrebi etike, jer bez toga revolucionarna praksa svakako ne može, ali je pogrešno što Bernštajn teži jednoj apsolutnoj socijalističkoj etici koja je kao izvor večitih principa iznad istorijskih prilika modernosti. Po Panekuku, etika je revolucionarno stanovište do kojeg treba doći iz konflikta modernosti, pa je ona nešto što se u klasnoj borbi tek formira i afirmiše.

\section{SUKOB O REFORMIZMU}

Pristalice revolucionarne strategije (Lenjin, Luksemburg, pa i Panekuk) i pristalice centrističke politike ortodoksije (Kautski kao najistaknutiji predstavnik) bili su saveznici protiv Bernštajnovog revizionizma. Kada je Kautski posle izbijanja Prvog svetskog rata branio oportunistički šovinizam socijalne demokratije koji je Internacionalu preko noći rasturio u paramparčad i povukao tepih ispod nogu svima onima koji su bili spremni da se ratu usprotive (spremni i na neodazivanje mobilizaciji), svi su bili iznenađeni. I ti, sine Kautski? U frakcijskim tučama koje su intenzivno izluđivale socijalnu demokratiju, pa bi o tome mogao da svedoči i Dimitrije Tucović koji se zauzimao za dogovor socijalne demokratije protiv austrougarske aneksije Bosne i Hercegovine, od samog početka videla se razlika između filozofske kritike Marksa i 
marksizma (Bernštajn) i ravnodušnosti prema svakoj teoriji. Tabor ravnodušnosti prema teoriji bio je jaka struja koja je tražila da se sukobi kakav je bio oko revizije Marksa jednostavno razreše tako da se sve teorije odbace u sferu subjektivnih predrasuda, tako da stranke uvažavaju samo diskusije oko konkretnih praktičnih ciljeva. Kautski se sve do rata nije ubrajao u redove ravnodušnih. Njegova je pozicija bila stav pravovernog teoretičara i sudije u teorijskim konfliktima. Njega su zvali u pomoć kada su hteli da završe ili osujete frakcijske borbe. Tom se ulogom učvrstio kao „sredinac“ koji se, kao i drugi ka centru usmereni nosioci značajnih funkcija u Internacionali već tada bar $u$ jednom na izgled manje značajnom akcentu razlikovao od stavova radikalne levice. Dok je levica u revoluciji videla jedinu strategiju jer se samo kroz potpuni prevrat može dokinuti kapitalizam i osnažiti socijalistički društveni odnosi, Kautski je kao i cela sredina u sukobe frakcija pokušavao uneti kompromis: revolucija jeste nešto čega se socijalna demokratija ne može odreći, ali „sada“ preostaju samo parlamentarna i sindikalna borba kao realni domet stranke, jer su „sada“ na tom nivou organizovanost i klasna svest radničke klase. U pogledima reformista koji su na početku rata metamorfizirali u oportuniste revolucija je bila čin za koji uslovi neće nikada postojati jer klasa nikada neće biti zrela za pravljenje revolucije.

Učlanivši se u stranku, Panekuk, kao i cela redakcija De Nuewe Tijd, postao je revolucionarni levičar. Sve dok nije u Holandiji došlo do masovnog štrajkačkog talasa (1903-4) i prve ruske revolucije (1905) razmimoilaženjima je bilo mesto u čistoj teoriji. A holandski štrajk kao i ruska revolucija bili su poraženi. Zašto? Revizija ili ortodoksija, reforma ili revolucija - to su sada bila pitanja o praksi i iz prakse, dok se od teorije očekivala kritička analiza koja će odgovoriti šta da se radi u sadašnjosti. U tim su se raspravama formirali razgovetni grupni stavovi reformizma i revolucije. Reformisti su doduše prihvatali masovni štrajk kao moguće sredstvo klasne borbe, ali samo ako je štrajk pod čvrstom rukom partijskog rukovođenja i ako to rukovodstvo smatra, da je situacija za tako nešto dozrela. Vodeća grupa holandske stranke nalazila je razloge za poraz štrajka u učešću anarho-sindikalista, jer su oni imali suviše velika očekivanja, pa su zbog toga delovali radikalnije od socijalne 
demokratije i ostalih radnika. Revolucionarna levica u SDAP, naprotiv, stavljala je pokret ispred stranke, a masovni štrajk nije shvatila samo kao sindikalnu već pre svega kao političku borbu. Zaključak da je štrajk bio poražen nisu prihvatili jer se kroz masovno učešće prikupilo dragoceno iskustvo. Upravo je to iskustvo radništvo ponelo od pukih sindikalnih zahteva do političkog programa koji je i dalje od značaja. Na lokalnom holandskom slučaju nalazimo polaznu suštinu sukoba u međunarodnoj socijalnoj demokratiji. S jedne strane je bila reformistička grupacija koja se kladila u izborne rezultate i parlamentarna postignuća, dok je u političkom štrajku videla samo pomoćno sredstvo; njoj nasuprot stoji revolucionarna strategija koja je, obrnuto, u parlamentarnom delovanju videla samo taktičko sredstvo. Panekuk se opredelio za revolucionarnu frakciju, čak je i zastupao njezine stavove na kongresu SDAP, ali sa vlastitim dodatkom koji i nije bio samo dodatak, jer je menjao celokupnu ideju. Prema toj ideji masovni štrajk javlja se kada se običnom štrajku pridruže i radnici koji nisu pogođeni izvornim razlozima; generalni štrajk je sindikalna eskalacija koja dolazi na dnevni red kada masovni štrajk istraje u sukobu i protiv sebe mobiliše protivnike s druge strane zajedno sa državnim strukturama i represivnim aparatima (zbog nedovoljnog odaziva radništva u toj je fazi štrajkački pokret u Holandiji bio poražen); politički štrajk znači prelazak iz štrajka u revolucionarni pokret sa svesno postavljenim ciljem promene celokupnog društvenog uređenja. $U$ te konceptualne pretpostavke socijaldemokratske levice Panekuk, od tada i kasnije ubeđen da je u procesima klasne borbe inicijativa uvek na strani radništva, unosi vlastiti stav: sindikati i stranke mogu biti samo sredstva. Uvažavajući i rusku revoluciju od 1905. godine dokazivao je da niti stranke, strukturirane kao grupe usredsređene na parlamentarnu borbu, niti sindikati usredsređeni na borbu za nadnice, skraćenje radnog vremena i druga poboljšanja nisu revolucionarne organizacije. Revolucionarna organizacija može biti isključivo samoorganizacija radništva u radničkim savetima koji u svoje ruke preuzimaju organizaciju proizvodnje i time dokidaju privatno vlasništvo sredstava za proizvodnju. Kao što u razmimoilaženjima o revizionizmu i ortodoksiji razlika između ortodoksije centrista i levice nije bila vidljiva, tako sada nije bila vidljiva razlika između Panekuka i levičara poput Lenjina ili Roze Luksemburg. 
Ipak, ta je razlika već postojala. Frakcijske borbe predstavljaju polje čiji se delovi podižu i propadaju, tako da Internacionala i svaka stranka ponaosob podsećaju na talasajući čaršav. Ljudi se miču od jedne grupe do druge i menjaju pripadnost a da pri tom često uopšte ne promene ono što sami zastupaju. Prelazi iz jedne u drugu frakciju dešavaju se zbog toga što se u pomacima talasajućeg polja traži mesto odakle se zadržava izvorni vlastiti stav. Grupa De Nieuwe Tijd je krenula u konflikt sa rukovodstvom SDAP, da bi na kongresu u Utrehtu 1906. godine bila potučena do nogu. U samo nekoliko godine preobrazili su se iz romantičarskih spasilaca čovečanstva u marksističke revolucionare, ali su se zbog toga udaljili od glavnog toka pokreta koji ih je okarakterisao kao intelektualne sanjalice bez kontakta sa stvarnošću: svima je poreklo bilo buržujsko, a kretali su se u krugovima elitne kulture ${ }^{3}$. SDAP se posla kongresa preobrazio u reformističku (malo)građansku stranku a da na to količina članstva ,čistog radničkog porekla“ nije nimalo uticala.

Panekuk je posle toga napustio Holandiju jer tu više nije mogao biti politički aktivan, dok se njegov rad u opservatoriji sadržavao od dosadnog upisivanja podataka u protokole. Prebegao je nemačkoj socijalnoj demokratiji koja je tada bila najsnažnija radnička stranka evropskog kontinenta i prema kojoj su se podešavali časovnici u celokupnom socijaldemokratskom pokretu. Da bi selidba bila što bezbolnija pomogao mu je Karl Kautski koji mu je sredio i zaposlenje na partijskoj školi. Panekuk se tada smatrao njegovim učenikom. Posao učitelja oduševljeno je prihvatio jer je bio ubeđen da marksizmu treba široko ljudsko razumevanje i prepoznavanje istorijsko materijalističke uslovljenosti vlastitog činjenja. Njegovu misiju vrlo brzo je zaustavila policija koja je njemu i Hilferdingu zabranila rad u obrazovanju jer nisu

${ }^{3}$ Herman Gorter i Henrijete Roland Holst nisu bili samo osobe građanskog porekla već pre svega najznačajniji predstavnici modernističkog talasa i generacije holandske umetnosti na pragu dvadesetog veka. Ako ne izvan tog kruga, bar u sazvežđu holandske umetnosti i kulture njihov je sjaj ravan Panekuku u astrofizici. Njihovi politički stavovi koji su išli od levice u socijalnoj demokratiji Druge intrernacionale do radikalne levice, zbog čega su morali biti izbačeni iz Treće internacionale, vidljivi su na upečatljiv način i u njihovim umetničkim i prirodnonaučnim delima. Tim poglavljem se nažalost ovde nećemo baviti, ali zavređuje dodatnu pozornost. 
imali ni stalni boravak ni nemačko državljanstvo. Na Panekukovo mesto $\mathrm{u}$ školi zaposlena je Roza Luksemburg koja je stalni boravak imala zbog fiktivnog braka sa Gustavom Lubekom. Kako bi nešto radio, pa i finansijski se održao, prihvatao je privremene zadatke i ugovorna dela kao pisac za socijaldemokratske novine i časopise, te kao predavač koji je prokrstario Nemačkom uzduž i popreko. $\mathrm{Na}$ nemačkoj socijaldemokratskoj sceni proslavio se kao oštrouman marksistički komentator aktuelnih zbivanja.

Ostao je aktivan i u holandskim partijskim prepirkama u kojima je levica napadala vođu SDAP Pitera Jelesa Trelstru i savetovala ga da se ugleda na - Kautskog. Ulogu De Nuewe Tijd je 1907. godine preuzela revija De Tribune koja je napadala Trelstru kao zagovornika parlamentarnog reformizma. Trelstra se zbog toga, posebno zbog Panekukovog učešća u napadima, žalio Kautskom smatrajući Panekuka njegovim štićenikom i učenikom, pa je Kautski odgovorio odbacivanjem Panekukovog forsiranja revolucije kao strategije. Štaviše, njegovo oduševljenje revolucionarnim sredstvima okarakterisao je kao anarhistički odnos prema državi. Ta je polemika važna jer je po prvi put jasno pokazala razliku između revolucionarne (Panekuk) i reformističke strategije (Kautski), pa ju je kao tipičnu kasnije navodio Lenjin u Državi $i$ revoluciji (Lenjin, 1975, original 1917). Panekukova strategija bila je sinteza Marksove analize Pariske komune i iskustava prve ruske revolucije za koju je smatrao da znači početak doba krize kapitalizma bremenite revolucijom. U revolucionarno doba proletarijat prelazi neposredno $\mathrm{u}$ ustanak $\mathrm{u}$ kome se iz manjih štrajkova i političkih demonstracija (na primer za univerzalno pravo glasa - tada značajan politički zahtev socijalne demokratije) koje buržoazija i državni aparat pokušavaju ugušiti upotrebom svih ekonomskih i političkih sredstava sve do otvorene upotrebe sile, stvara zajednički talas otpora i ustanka. Kroz suočavanje postaje jasno da treba odnose moći u državi preokrenuti iz temelja. Radnički saveti iz samoorganizovanja radništva u štrajku pretvaraju se u alternativu državnom aparatu. Ako je izvorna ideja komunizma iz Komunističkog manifesta ukidanje privatne svojine nad sredstvima za proizvodnju, onda mu se sada dodaje osnivanje radničkih saveta kao centralna ideja komunizma. Sredstva kojima se to može 
postići su različita, jedno od njih je i generalni odnosno politički štrajk, ali mogu to da budu i izbori ili revolucija. Saveti moraju prvo preuzeti upravljanje sredstvima za proizvodnju. Kada je to postignuto, stvaranjem mreže saveta počinju se donositi zajedničke odluke i stvara se alternativna organizacija društva. Karakteristika te mreže, kaže Panekuk, jeste odsustvo piramidalnog odnosa, dakle hijerarhije saveta i nivoa odlučivanja kakva je tipična za birokratski državni aparat. Tako nastaje samoupravni sistem odlučivanja zajednice radnika i radnica. Kautski je u tome prepoznao anarhizam, i otvorio svoje karte: država je po njemu neutralan plen koji treba samo osvojiti i primeniti ga za dobro radničke klase. Što se njega tiče, revolucija nije isključena, ali i revolucija je samo sredstvo za donošenje reformi unutar parlamentarne demokratije. Ono što je za Panekuka strateška svrha za Kautskog je samo taktičko sredstvo, i obrnuto. To što je na dva kraja Evrope, u Holandiji i u Rusiji, došlo do masovnih štrajkova i pobuna, u Rusiji i do masovnog revolucionarnog pokreta, po Panekuku znači da se došlo do kraja razdoblja parlamentarne konkurencije i konflikata. Radnička klasa stavila je na dnevni red radikalnije zahteve od onih koji se mogu plasirati u parlamentarne diskusije ili u sindikalne zahteve. Dok je pisao Državu i revoluciju, Lenjin je imao u rukama nemačko izdanje Panekukove rasprave „Masovna akcija i revolucija“ (Panekuk, 1912c) i na osnovu tog izvora zapisao da mu kod Panekuka smetaju neke tvrdnje koje inače za pobijanje reformizma nisu bitne. Kao i Kautskom koji je upravo na tome pobijao Panekuka, Lenjinu je smetala formulacija da je samoorganiziranje proletarijata po svojoj suštini „nešto duhovno“ (etwas Geistiges), pa je pripisao na ivici teksta da to nije prikladna reč. (Lenjin 26, 1917, 476477) Ta „duhovnost“ o koju su se spotakli i Kautski i Lenjin (Kautski je u tome video dokaz da čovek uopšte nije marksista), ukazuje na jedan od razloga zbog kojih je Panekuk kasnije odbacio Lenjinov marksizam i opredelio ga kao buržoaski odnosno vulgarni materijalizam. U kontekstu sukobljavanja o taktici i strategiji pre Prvog svetskog rata Panekuk je duhovnost spominjao kao rezultat najboljeg mogućeg vaspitanja odnosno „prosvećivanja“ masa: pobuna, štrajk, demonstracija, revolucija - to su škole proletarijata i njegov duhovni obrazovni proces. Nova duhovnost oličena je u hrabrosti, odlučnosti, solidarnosti i spremnosti na borbu, 
dakle sve ono što bi se moglo nazvati revolucionarnom etikom. Prethodni oblici obrazovanja u kojima se Panekuk uveliko angažovao u Holandiji i u Nemačkoj mogu tog duha da probude, ali bi bila, kaže Panekuk, velika greška smatrati da se može radništvo pomoću nekakvog $\mathrm{ABC}$ revolucije ili $\mathrm{ABC}$ marksizma podučiti o tome šta treba da se radi. U odnosu na argumente koje je protiv njega razvio Kautski, Panekuku je najviše smetalo obilato navođenje Marksa i Engelsa koje je služilo opredeljivanju udaljenosti Panekukovih pogleda od ortodoksnog centra marksizma. Njegov je odgovor na takvu metodu bio da nema nikakvog smisla o razlikama o pogledima na sadašnju situaciju raspravljati sa pozivanjem na nekakvo „sveto pismo“, i time razmimoilaženje o aktuelnim odlukama potisnuti u sferu interpretativne ortodoksije. Ono što treba interpretirati nisu sabrana dela Marksa i Engelsa već sadašnjost, vraća Kautskom Panekuk. Kad bi se marksizam tumačio striktno prema odnosnoj potki njegove istorije, na tom bi se mestu moglo zaključiti (i time potvrditi konstataciju Kautskog) da Panekuk više nije marksista, jer je odbacio ortodoksiju kao ideju vodilju.

Dok su Panekuk i Kautski započeli polemiku u Holandiji, varnica konflikta na liniji revolucija ili parlamentarna reforma stigla je i u krugove nemačke socijalne demokratije. Panekukovi stavovi iz 1912. godine na koje se poziva Lenjin nisu više iz holandske polemike već iz proširene arene gde se našla kompletna svetska socijaldemokratija. U času kada se klasna borba zaoštravala i radnička klasa počela da nastupa odlučnije i samouvereno, kada se osećalo da je veliki rat za podelu sveta kao imperijalističkog plena već tu iza ćoška, i kada je postajalo evidentno da će u takvom sukobu tuđe ambicije i interese glavom platiti upravo narodne mase $-\mathrm{u}$ tom trenutku nastupa i kriza socijalne demokratije. To nije ona kriza o kojoj je kasnije pisala Roza Luksemburg nego prethodna, još uokvirena slobodnim dijalogom ali izgovarana nepopustljivim polemičkim tonom. Ona je stavila do znanja da se uprkos isključivanju revizionizma ortodoksna koalicija oportunista i levice neće moći održati. Nesuglasice su počele sukobom između Karla Kautskog i Roze Luksemburg o masovnom štrajku, pa je Roza Luksemburg pozvala Panekuka da se angažuje jer je odranije imao polemičkog iskustva sa Kautskim. Panekuk se odazvao, a polemika o masovnom štrajku se 
razvila u sukob o imperijalizmu i razoružanju i eskalirala u konflikt o izbornim trgovinama i odnosu socijalne demokratije prema liberalizmu. (Panekuk, 1912a, 1912b i 1912c) Nije više bilo nijedne teme iz arsenala parlamentarne politike socijalne demokratije koja nije bila duboko osporavana, a stranke zbog njih neprijateljski razdvojene. Panekuk je bio nezavisan od Kautskog zbog toga što je s njim imao polemičko iskustvo iz Holandije, ali još više zbog toga jer je u međuvremenu u Bremenu dobio mesto učitelja koje su ponudili sindikati i lokalna socijalna demokratija. Primljen je bio na osnovu referendumskog glasanja svih članova sindikata i stranke. Neposredna demokratija bila je zaštitni znak bremenske radikalne leve većine kojoj je Panekukov profil posve odgovarao. Četiri godine, od 1910. do početka Prvog svetskog rata, tu se osećao kao riba u vodi. Prvi, pa i poslednji put u životu bio je intelektualac zaposlen od strane radnika, i aktivista uvučen u planiranje mera za preuzimanje preduzeća i političke vlasti u ruke radničkih saveta. Prvi i poslednji put živeo je revolucionarni proces kakav je predvideo $\mathrm{u}$ teoriji. U raspravi „Marksistička teorija i revolucionarna taktika“ (Panekuk, 1912a) objasnio je da treba pre zauzimanja stava u konfliktu između tri socijaldemokratske strategije (revizija, reforma, revolucija) istorijsko-materijalističkim metodom shvatiti kako je to razmimoilaženje prirodno i nužno. Razvoj kapitalizma je prouzrokovao masovni aktivizam radničke klase kojim je stavljeno na dnevni red pitanje socijalne revolucije. O tom se pitanju radi, o tome se svađaju tri pravca delovanja i mišljenja. Revizionizam se ograničava na parlamentarnu i sindikalnu taktiku uvođenja reformi za poboljšanje položaja radničke klase u kapitalizmu, a socijalizam očekuje kao prirodni ishod te evolucije. Preostaju dve radikalne taktike. Panekuk tvrdi da je revolucionarna taktika nužnost, jer je revolucionarni proces već započeo. Kautski i jezgro stranke naprotiv shvataju revoluciju kao neki događaj za koji smo kao socijalne demokrate doduše spremni, ali ne sada nego negde u nedoglednoj budućnosti. Odnos Kautskog prema revoluciji je pasivan, nastavlja Panekuk, njegov odnos prema radničkim masama je nesiguran i sumnjičav, jer mu neorganizovane mase izgledaju krajnje nepredvidive. Njemu bi odgovarala samo jedna predvidiva revolucija, dakle takva kojom bi se moglo ovladati. Bez obzira na razliku u odnosu prema 
ortodoksiji, što se tiče revolucije revizionisti i Kautski su praktično jednaki. Revolucionari, naprotiv, u neorganizovanim masama ne vide pretnju, jer u masovnoj akciji proleterski klasni karakter dolazi u punoj meri do autentičnog izraza. Za Kautskog revolucija znači jednokratan i više-manje nasilan događaj preuzimanja institucionalizovane političke moći u vlastite ruke, dok Panekuk smatra da je revolucija dugotrajan proces uspona i padova $\mathrm{u}$ kome mase uče upravo iz sukoba sa kapitalistima i buržujima sve ono o čemu nikakva teorija ne može da podučava unapred. Svakodnevne ,redovne“ akcije koje Kautski radosno podržava, na primer borba za univerzalno pravo glasa, Kautski razume odvojeno od revolucije dok Panekuk svaku od tih akcija sagledava kao korake same revolucije. Direktno izraženo: nema nijednog cilja, nijedne programske tačke, nijednog činjenja socijalne demokratije u kome ne bi bilo nezaobilazno zastupanje revolucije u celini. Pojedinačni koraci razgolićuju taktiku i strategiju protivnika, i podstiču ljutnju, hrabrost, odlučnost i spremnost na klasnu borbu kao barut revolucionarnog naboja. Panekuk smatra da je polje za borbu već određeno kao i revolucionarne snage koje su se suprotstavile na njemu. Njegov glavni argument protiv Kautskog jeste da ja napuštanje polja bez borbe gore od poraza. Umesto spremnosti na akciju, kakvu bi trebalo da ispoljavaju, umesto da čuvaju mesto za revoluciju u nekoj nedostižnoj budućnosti, kautskijanski reformisti radništvo koče i zadržavaju akciju, pa i revoluciju.

Kao što su svi počevši od Nemačke pa nadalje bili ,iznenađeni““ početkom rata, socijalni su demokrati bili „iznenađeni“ još i vlastitim glasanjem za rat usprkos svim prethodnim zaklinjanjima u pacifizam i protiv šovinizma i militarizma. Preko noći su se rukovodstva pretvorila u šakale rata i saveznike nacionalnih buržoazija, blagosiljajući smrt svojih dojučerašnjih saveznika iz Internacionale. Kao što je iznenađenje, ipak, bilo lažno u prvom slučaju jer je rat bio na dohvat već duže vreme i svi, pa i socijalni demokrati su odavno o njegovom nužnom izbijanju odavno prozborili, tako je bilo iznenađenje lažno i u drugom slučaju. Završavajući članak „Klasna borba i nacija“ iz 1912. godine Panekuk konstatuje da može nacionalni oportunizam da bukne i iz socijalnih demokrata, što će nas naterati da biramo između nacionalnih i proleterskih interesa. „A kada dođe odlučujući trenutak, kada ćemo biti 
prisiljeni da izaberemo između nacionalnih i proleterskih interesa, unutrašnja će slabost ovog radničkog pokreta postati vidljiva...“ (Panekuk, 1912c) Rat protiv rata, na što je celokupnu Drugu internacionalu obavezivala debela hrpa manifesta i izglasanih kongresnih stavova, trebao bi biti ,početak procesa revolucije koja vodi iz kapitalizma u socijalizam.“(Panekuk, „Rat protiv rata“, 1913)

\section{SUKOB O KOMUNIZMU}

Umesto da odbijanje kapitalističkog rata bude novi korak revolucije, socijalna je demokratija prigrlila šovinizam i militarizam. Panekuk je Prvi svetski rat procenio kao dvostruku katastrofu - kao rat za interese imperijalizma i kao propast socijalne demokratije. Stao je uz cimervaldsku levicu i sarađivao sa onima koji su očekivali kraj rata kao novi trenutak za revoluciju. Levica se posle ruske revolucije organizovala u Treću, komunističku internacionalu. Ni ova nije bila jedinstvena grupacija. Već 1922. godine, jedva okupljena, prošla je kroz sukobe i prelome, kroz duboka strateška i taktička razmimoilaženja, pa i kroz čistku posle koje su Panekuk i njegovi istomišljenici bili isključeni kako iz komunističkih tako i iz socijaldemokratskih redova. Smatrao je da je nastupila situacija za koju nikakve interpretacije Marksa i marksizma, pa ni dotadašnja iskustva parlamentarne ili sindikalne borbe ne mogu nuditi uporište. (Panekuk, 1917b) Šta onda preostaje? Treba biti neprestano usred aktuelnih konflikata koji donose delimične pobede i delimične poraze. Tek iz tog učešća može niknuti novi teoretski oslonac. Kamen temeljac je već tu, to su radnički saveti, neprestano ponavlja Panekuk svoju mantru, jer su oni pravi organizacioni izraz socijalne moći proletarijata. Ali se toj misli vodilji već u članku „Kad rat prođe“ (Panekuk, 1917a) pridružuje tvrdnja da treba radikalni pokret saveta suprotstaviti državnom socijalizmu, jer državni socijalizam i nije neka velika promena - on je samo način za očuvanje kapitalizma/imperijalizma u času njegove posleratne ugroženosti. Radnički se saveti prema Panekukovom ubeđenju nisu pojavili samo zato da bi posle kratkog perioda revolucionarnog ustanka kao u Nemačkoj 1918. godine predali svoju moć i vlast državi, stranci i parlamentarizmu. 
Socijalizam je nešto više od nacionalizacije industrije koja proizvodi podržavljeno privatno vlasništvo. Socijalizam znači snagu proletarijata, a da bi proletarijat bio snažan, on mora eliminirati eksploataciju i na nov način organizirati celokupan ekonomski sistem. Eliminacija eksploatacije za Panekuka znači oduzimanje kapitala u smislu prava na raspolaganje viškom vrednosti. Diktatura proletarijata - to su radnički saveti koji nezavisno i umesto ovisnosti od države i stranaka donose odluke. Oni izgrađuju vlastiti mehanizam međusobnih odnosa prema načelu supsidijarnosti, kroz delegatsko donošenje odluka, jer na taj način ne može doći do nadređenosti i podređenosti. Hijerarhija uvek znači da u društvu postoji centrala koja donosi odluke i sve druge stavlja u odnos sprovođenja odluka o kojima nisu imali prilike da odlučuju. Panekuk se doduše slaže da će se oduzimanje raspolaganja viškom vrednosti sa prenosom na radničke savete morati izvesti valjanim pravnim činom, ali taj pravni čin će izostati ili neće imati pravnu moć ukoliko moć već ne bude bila u rukama radničkih saveta odnosno samih radnika i radnica. Pošto je kamen temeljac prelaska u socijalizam moć radnika, to se čini utopijskim projektom, posebno na Zapadu gde je kapitalizam u punoj snazi (za razliku od Rusije), tako da radništvo i ne veruje da ga se može pobediti. To znači da ustupaju pred ideološkom snagom kapitalizma, kaže Panekuk - Gramši bi to kasnije nazvao hegemonijom. U toku posleratnog perioda Panekukovi se stavovi razvijaju i učvršćuju sve do programskog teksta „Svetska revolucija i komunistička taktika“ (Panekuk, 1920) kojim se na uočljiv i izričit način pridružio ostalim adresatima Dečje bolesti levičarstva u komunizmu (Lenjin, 1976, rusko prvo izdanje 1920.) koja je podeljena učesnicima drugog kongresa komunističke (treće) Internacionale kao pripremni dokument za diskusiju. Iz samog teksta, kao i iz diskusija na drugom i trećem (1921.) kongresu Kominterne, kako su je kasnije zvali prema sovjetskoj navici stvaranja nezgrapnih skraćenica, kao i iz prethodnih objava i kasnijih reakcija „levičara“ na Lenjinovu kritiku, može se razabrati o čemu se radilo: da li je iskustvo ruske revolucije nešto prema čemu se Zapad mora ravnati i učiti? Poenta tog iskustva se već u prvim godinama, od 1919. dalje kada se desio prvi kongres (na kome je prisustvovala jedva nekolicina delegata sa važećim mandatima pa je kongres u stvari samoga sebe proglasio kongresom) do 
1921. bitno menjala prateći promene međunarodne i domaće ruske odnosno sovjetske situacije. U tom kratkom razdoblju kada se radilo o opstanku revolucijom osvojene političke moći svi su imali zajednički polazni stav da je kapitalizam zaglibio u duboku krizu koja je bremenita i njegovim potpunim kolapsom - revolucija je na svetskom dnevnom redu. Treća, komunistička internacionala se upravo stavom „Ako ikada, revolucija sada!" ponajviše razlikovala, pa se posle prihvatanja slavne 21 tačke uslova za prijem taj stav upotrebljavao kao kriterij za razdvajanje socijalno-demokratskih stranaka i pokreta na Zapadu na oportunističku i reformističku socijalnu demokratiju i revolucionarnu komunističku stranku. Gledano kroz Panekukove studije strategije i taktike posleratnog revolucionarnog pokreta (pa i kroz tekstove drugih teoretičara $u$ holandskom i nemačkom „levičarenju“) ono što je Lenjin gurao u prvi plan i što je kasnije postalo prepoznatljiva pozicija dečjih bolesti - uopšte nije bilo karakteristično za sve one koji su iz tog sukoba izašli kao isključeni gubitnici ili su sami ostavili komunističku, od tada u stvari lenjinističku Internacionalu. Štaviše, Panekuk stoji čvrsto upravo na suprotnoj strani od levičarstva kako ga je definisao Lenjin. Ne samo da se ne zalaže za jednokratni revolucionarni čin preuzimanja vlasti koji bi omogućio prelazak iz kapitalizma u socijalizam, nego se takvom shvatanju izričito protivi. Revolucionarni proces koji započinje, smatra Panekuk, bit će dugotrajan i promenljivog toka, i nikako ga ne treba zamišljati kao ustanak kojim preuzmemo u svoje ruke državne ustanove i upotrebimo njihovu snagu za uvođenje socijalizma. Gde je onda tačka razlikovanja levičara i Lenjina? Kakva bi trebala da bude uloga države, parlamenta, političke stranke i sindikata u dugotrajnom i promenljivom toku revolucije? Država na Zapadu, smatra Panekuk, nije takve prirode da bi ju se moglo jednostavno uzeti u svoje ruke i upotrebiti u svrhu socijalizma, jer je ta država do kraja kapitalistička a ne caristički autoritarna, a pored toga socijalizam se ne može uvoditi odozgo, jer bi u tom slučaju glavni mehanizam revolucije postao hijerarhijski složen birokratski aparat. Parlamentarna demokratija, tako Panekuk, u Rusiju je stigla slabašnim korakom sa Februarskom (buržoaskom) revolucijom, a parlamentarna diskusija je zbog skučene i onemogućene javnosti bila od posebnog javnog značaja. Na Zapadu je parlamentarni oportunizam 
socijalnih demokrata pre rata, za vreme rata i posle rata prouzrokovao otpor prema parlamentarnom taktiziranju, posebno takvom koji bi od komunista tražio da se priključe socijalnim demokratima (to je Lenjin tada tražio od komunista na Zapadu). Panekuk nikada nije prestao da dokazuje da ne postoje nikakvi nužni revolucionarni razlozi za ulazak u parlament, čak ni kasnije, u situaciji koja je bila daleko od revolucionarne. Komunisti treba da se zalažu za osnivanje radničkih saveta, ne za osnivanje stranaka koje preko izbora ulaze u parlament i sklapaju koalicije, jer radništvo može dobiti na snazi samo tim putem, dok parlamentarno zastupništvo daje razloge samo za pasivizaciju masa i korumpiranje elita. Oko uloge komunističke stranke Panekuk ostaje na izvoru: komunisti nisu (još) jedna od stranaka. Njihov osnovni cilj nije ući u parlament i doći do vladavine nego opunomoćenje radničke klase sa strane najsvesnijeg, najhrabrijeg i najradikalnijeg skupa pojedinaca $\mathrm{i}$ pojedinki, ali to nikako ne sme da bude odnos između prosvećene elite koja zna i mase kojoj je uloga da prihvati i prati. Panekuk ne smatra da se u odnosu između partije i radništva radi o transferu znanja. Stranka je pre pozvana da omogućuje metodičko donošenje zaključaka pre konflikta, za vreme akcije, i posle poraza ili pobede. Ako je, dakle, za Lukača metod najbitnija Marksova teorijska zaostavština, za Panekuka je uloga partijski organizovanih komunista da brinu o doslednosti metoda promišljanja pre, za vreme, i posle delovanja. A za takvo mišljenje ne postoji već zgotovljeno znanje, na tom polju nema habilitiranih učitelja i učiteljica. Mišljenje treba biti mišljenje pokreta i u pokretu. Slično kao za stranke važi i za sindikalne organizacije, gde Panekuka posebna smeta što su zbog podele rada između stranke i sindikata sindikati postali apolitični, ograničavajući se na takozvane sindikalne zahteve, dakle na nadnicu, radno vreme i opšte uslove radnog procesa. Jasno: sa njegovog aspekta upravo je konflikt u proizvodnji najočitiji politički konflikt napunjen revolucionarnim nabojem, a taj naboj je revolucionaran zbog toga što može u svakom trenutku ukinuti partijsku i sindikalnu birokratiju i uzeti stvari u vlastite ruke.

Nestrpljivost je bila zajednička karakteristika ljudi i grupa koji su se posle rata odvajali od socijalne demokratije i prilazili komunističkoj Internacionali. Razlika koju je Lenjin označio „dečjom bolešću“ bila je u 
isticanju razlike između ruske situacije i položaja na evropskom Zapadu. Jedna je strana dokazivala da su neka od ruskih iskustava već postala i principi koje treba svi da prihvate i na Zapadu, a druga se strana odupirala dokazivanjem da je ruska revolucija nikla u bitno drukčijim uslovima, pa nije još nimalo jasno šta će u tim uslovima od nje da nastane. Panekuk, ali i Herman Gorter i Henrijete Roland Holst iz Komunističke stranke Holandije (koju su već 1921. godine napustili osnivanjem Radničke komunističke stranke Holandije) unutar su tog razlikovanja isticali spontanost pokreta saveta protiv centraliziranog ,jedinonačalja“4 Nešto od toga pre bismo mogli da nađemo u promišljanju onih koji su se 1920. godine nadali da će komunizam doći u Evropu na bajonetima Crvene armije - a takvih nije bilo malo ni na Zapadu ni u Rusiji, posebno kada se Crvena armija spustila sve do ispred Varšave. Tada se to napredovanje zaustavilo upravo $\mathrm{u}$ vreme zasedanja 2 . kongresa Kominterne, što je na neke od učesnika delovalo krajnje razočaravajuće, i bitno uticalo na promenjeni kurs Internacionale. To ne znači da je bio Panekuk u pravu dok je Lenjin pogrešio, ali znači da je Panekukovo usmerenje bilo čvrsto, dok su se Lenjinova shvatanja, kao i ubeđenja i stavovi Internacionale kao celine menjali ovisno od trenutnih okolnosti, a pre svega ovisno od interesa očuvanja revolucionarne diktature u Sovjetskom savezu. Marginaliziranje zapadnih komunista, pa i njihovo istiskivanje omogućili su da je iz Treće, komunističke internacionale nastala Kominterna kao mehanizam koji je iz Petrograda odnosno Moskve upravljao strankama cele Evrope i sveta. Globalna perspektiva Kominterne bila je određena njenim sedištem. Od 21 uslova za prijem u Kominternu najbitnija je tačka 16 koja traži od svih članica da bez iznimke sprovode zaključke kongresa i uputstva izvršnog komiteta. Što se različitih uslova u raznim delovima sveta tiče, „lokalci“" moraju prvo

\footnotetext{
${ }^{4}$ Princip »jedinonačalja komunizma « (1918-1921.) kako bi se odluke značajne za sve donosile na jednom te istom centralnom mestu, odakle se onda putem mreže političkih institucija i produkcionih jedinica dogovoreni potezi sprovode. Za taj način upravljanja bilo je, pored pritiska građanskog rata, verovatno značajno i to da su za Lenjina idealno uređenje društvenog mehanizma bili austro-ugarska pošta i američki tejlorizam. Princip jedinonačalja je nadživeo ratni komunizam.
} 
ubediti centralu da te različitosti postoje, ako žele da dobiju bar malo manevarskog prostora za delatnost u vlastitoj zemlji.

Kada je Lukač 1967. godine pristao na ponovno štampanje Istorije $i$ klasne svesti (Lukač, 1970, drugo izdanje sa novim predgovorom 1986.), u predgovoru novom izdanju okarakterisao je svoj bečki period $\mathrm{u}$ azilu posle poraza mađarske revolucije kao razdoblje studija Lenjina i stalnih kontakata sa nemačkim, francuskim, italijanskim i drugim komunistima. Časopis Kommunismus koji je uređivao od 1919. do 1922. sada je ocenio kao organ ultralevih struja. „Pored austrijskih komunista, mađarskih i poljskih emigranata koji su predstavljali unutrašnje jezgro i stalnu grupu saradnika sa njihovim su nastojanjima simpatizirali i italijanska krajna levica Bordige i Teračinija, holandska Panekuka i Roland Holstove itd." (Lukač, 1967) Sa tih i takvih levičarskih pozicija pred sam izlazak knjige Istorija i klasna svest 1922. godine napisao je poslednji članak „Metodički doprinos organizacionom pitanju“ (Lukač, 1986) u kome procenjuje (sada već za posleratno razdoblje) da je za pokret socijalno-demokratske levice sa Rozom Luksemburg i Panekukom bilo sudbonosno to što nisu shvatili jedinstvo koje spaja dva ključna pitanja u sukobu pravaca unutar Druge internacionale. To su pitanje o karakteru revolucije koja se već pomaljala kao mogućnost, i organizaciono pitanje. Pošto levica ta dva pitanja nije uspela da spoji u jedno, „zadržala je utopijski karakter.“ (Lukač, 1967) Posle Prvog svetskog rata i dovršenog raspada političkog dela radničkog pokreta na socijalnu demokratiju i komunizam, ta se nepovezana podvojenost „duha vremena“ i njemu pripadajućeg načina organizovanja ponovila u sukobu u komunističkoj Internacionali u godinama 19201922. Iz tog su procesa s jedne strane izašle „očišćene“ komunističke stranke povezane u hijerarhijski organizovanu i iz centra rukovođenu internacionalnu organizaciju koja je sve više i više slepo i poslušno sprovodila zahteve Moskve, odakle se upravljalo svetskom situacijom prema tome kakva je izgledala - iz Moskve. Na drugoj su strani ostali izbačeni ili izgurani radikalni levičari koji su svoju radikalnost mogli izraziti više u utopijskim uzletima nego u organizacionim posledicama, pa su gajili mesijansku nadu da će doći do spontane eksplozije revolucionarnog proletarijata. Time će levičari biti ponovo pozvani u 
istorijsku praksu u kojoj će, umesto slanja partijskih direktiva, pomoći u objašnjenju i menjanju prilika, podizati spremnost i hrabrost posle poraza i osposobiti za kritiku posle pobeda. Tim grupama, a posebno jednoj od njih - komunistima saveta - od tada je pripadao i Antoni Panekuk. One su rezultat dugog procesa konflikta (tu smo naveli samo tri najveća i sudbonosna za internacionalni pokret u celini) koji su svaki put završili čistkama i novom centralizacijom moći. Čišćenje je u slučaju anarhista na početku i levičara na kraju procesa delovalo doslovno kao isključivanje, dok se u međuvremenu radilo o marginaliziranju. Bez obzira na način čišćenja tim je procesima kao posredstvom vezanog suda na drugoj strani odgovaralo učvršćenje centralizacije i ideološke ortodoksije. Kominterna je uvela princip čistke kao nužni i ponavljajući elemenat izveden iz boljševičkog iskustva: za članstvo nije dovoljno opredeljenje za program i plaćanje članarine, potrebno je dejstvovanje u strankinim akcijama. To dejstvovanje mora biti jedinstveno, a jedinstvo se postiže eliminacijom opozicije koja se stvorila tokom prethodnih rasprava. Rezultat procesa usklađivanja i čišćenja je, u slučaju komunističke internacionale, s jedne strane vojničko organizovanje globalne komunističke stranke a sa druge strane eliminisana, labava i prevashodno intelektualno aktivna radikalna levica bez prave organizacije. Drugi rezultat bila je podela na zapadni i sovjetski marksizam kod koje je za zapadni marksizam bilo karakteristično, rečima Perija Andersona, ,strukturno razmimoilaženje sa političkom praksom“ (Anderson, 1985, 77) i prebacivanje pažnje sa političke ekonomije ka filozofiji. (Anderson, 1985, 105) Anderson prepoznaje epohalni značaj Lenjinove kritike levičarstva (Anderson, 1985, 63-64), ali samo u smislu procene kako je Lenjin snažan marksistički teoretičar a ne samo vođa revolucije - dakle u ortodoksnoj lenjinističkoj maniri. Zato razvod između istočnog i zapadnog marksizma smatra posledicom zapadnog poraza $\mathrm{i}$ istočne pobede revolucije, a odvojenost zapadnog marksizma od političke prakse posledicom staljinizacije komunističkih stranaka. Zbog takve procene može se prikazati razliku unutar teorije marksizma, pa i unutar komunističke prakse kao geopolitičku pojavu. U stvari radi se o cepanju Treće internacionale koje je pokrenuo proces između drugog i trećeg kongresa prihvatanjem uslova za prijem i Lenjinove brošure kao oznake pravilne 
orijentacije. Kada uzmemo oba dokumenta zajedno, a tako su i prihvaćena i tako su delovala, kao zaraženi od dečjih bolesti (a dečje bolesti su tada još bile smrtno opasne) levičarstva su prozvane celokupne, jedva nastale komunističke stranke nekih zemalja, ili označeni pojedinci i pojedinke koji su posle tog prozivanja imali izbor između ostajanja u dodiru sa političkom praksom koju su smatrali pogrešnom, ili prelaza u izolaciju u malobrojnim grupama ili u potpunoj osami. Način na koji je Lukač izabrao pripadanje čvrstoj organizaciji i odrekao se svojih shvatanja za njega je svakako karakterističan. Panekuk se opredelio za put usamljenog jahača koji ne dozvoljava sebi da s vremena na vreme, posle novih poraza i sukoba u socijalnoj demokratiji ili komunističkom pokretu, ili posle strave i užasa staljinističkih represalija progovori u maniru ,je li sam vam to na vreme rekao?", ali ipak u svakom trenutku sledećih decenija nanovo progovara analizu koja je bila spremna i 1920. godine. U organizacionom smislu bio je ograničen na izdavanje ovog ili onog časopisa iza kojeg osim štampanja tekstova nije stajala nikakva spomena vredna politička grupacija, dok mu je u teoretičkom smislu posle 1922. godine preostalo da okarakteriše rusku revoluciju i iz nje nastale društvene formacije, i da odgovori na pitanje kakve su istorijsko materijalističke okolnosti kumovale Lenjinovoj poziciji u godinama revolucije i formiranja komunističke Internacionale. Kada je to bilo obavljeno preostalo je samo da se pobrine za prenos ostavštine komunizma saveta na sledeće generacije.

\section{DRŽAVNI KAPITALIZAM I BURŽOASKI MATERIJALIZAM}

Sukob u ranoj fazi komunističke Internacionale na liniji procene o prenošenju strategije i taktike sa Istoka na Zapad pripremio je teren za sve što je kasnije Panekuk napisao o sovjetskoj revoluciji i Sovjetskom savezu: ne radi se o socijalističkoj revoluciji nego o buržoaskoj revoluciji u specifičnim zaostalim uslovima, i ne radi se o socijalističkoj zemlji već o zemlji državnog socijalizma, a državni socijalizam je samo podvrsta državnog kapitalizma. Gledano kroz rečnik ekonomske eksploatacije: u Sovjetskom Savezu se iskorištavanje radnika na osnovu privatnog vlasništva preobrazilo u iskorištavanje radnika na osnovu državnog 
vlasništva nad sredstvima za proizvodnju, i taj proces sada drži u rukama nova vladajuća klasa - birokratija. Panekuk to nije sročio kao predbacivanje ili odbacivanje sovjetske revolucije i državnog uređenja nego kao konstataciju o neizbežnoj realnosti ruskih prilika. On ne predbacuje na Lenjinove subjektivne sklonosti odgovornost za takvo stanje, niti govori o Staljinovoj ličnoj želji koja bi bila uzrok izgradnje totalitarnog sistema. Ali zato pripisuje neshvatanje različitosti okolnosti na Zapadu ruskom objektivnom pogledu koji je davao prednost očuvanju i osiguranju vlastite revolucije, posebno kada je postalo jasno da je revolucija na Zapadu doživela poraz (između ostalog i zbog pogrešnih uputstava Treće internacionale). U tekstu „Svetska revolucija i komunistička taktika“ (1920.) u dodatku na kraju kaže: „Sada je jasno zbog čega taktika Treće internacionale za koju se odlučio kongres kako bi je na isti način sproveo u svim kapitalističkim zemljama i upravljao njime iz centra, ne određuju samo potrebe komunističke agitacije u tim zemljama već i političke potrebe Sovjetske Rusije.“ (Panekuk, 1920)

Godine 1938. objavio je delo Lenjin kao filozof: Kritičke primedbe uz političke osnove lenjinizma (Panekuk, 1938) koja je rezultat čitanja Materijalizma i empiriokriticizma: Kritičke primedbe o jednoj reakcionarnoj filozofiji. (Lenjin, 1974) Istina je da je to, za ideologiju sovjetskog komunizma ključno delo, izašlo na ruskom jeziku već 1909. godine, ali se prvi engleski prevod pojavio tek 1927. kada je postao za zapadne marksiste pravo otkriće. U Sovjetskom Savezu, kao i u globalnom komunističkom vaspitanju, to je delo zauzelo mesto nezaobilaznog udžbenika marksizma - lenjinizma na akademskom nivou, dok je Staljinova pojednostavljena kompilacija „O dijalektičkom i istorijskom materijalizmu“ uneta u Istoriju svesavezne komunističke partije (boljševika): kratki kurs iz 1938. godine (ISKPb, 1947) poslužila kao obavezno masovno štivo koje je prihvatanje bilo kakvog naređenja Partije i njenog Oca pretvorilo u priklanjanje večitoj naučnoj istini.

Panekuk prilazi lenjinizmu pomoću paradoksa: boljševička revolucija je dovela do državnog kapitalizma sa novom vladajućom klasom, i marksizam bi trebao biti misaoni osnov te tvorevine. Kako se to može objasniti? Za početak treba sići u filozofske osnove doktrine koja se tu nudi kao marksizam. Ta je osnova, što se tiče ruskog marksizma i iz 
njega nastalog marksizma - lenjinizma, razvijena u Lenjinovom Marksizmu i empiriokriticizmu, koji je nastao posle invazije Mahovih filozofskih zamisli u socijaldemokratske i unutar njih i boljševičke redove, posebno izraženo u pogledima Bogdanova i Lunačarskog. Bez analize te knjige ne može se shvatiti ni nastanak partijskog komunizma ni Treća internacionala, kao što se Marksa ne može shvatiti bez poznavanja nemačke klasične filozofije, Hegela ponaosob. Za početak treba suprotstaviti istorijsko materijalistički odnos prema religiji buržoaskom materijalističkom odnosu. Panekuk dobro zna (i kroz Marksa i kroz Dicgena) da istorijski materijalizam počinje tamo gde kritika religije završava, i da je zbog toga usredsređen na kritiku sveta kakvom je religija nužna uteha, dok buržoaski materijalizam neprestano atakuje na religiju upravo zbog toga jer ju može shvatiti samo kao pogrešnu svest koja ne ume sebi na drugi način da objasni procese i promene prirode. „Prirodne nauke su duhovni kamen oslonac kapitalizma,“, kaže Panekuk. (Panekuk, 1938) Panekukov favorit u shvatanju razlike između pirodnjačkog buržoaskog materijalizma i dijalektičko-istorijskog materijalizma ostaje Jozef Dicgen, ovaj put zbog toga kako objašnjava razliku između sveta pojava i naučne slike sveta. Kao primer navodi pojavljivanje obojenog sveta koji je realan kao svet, u kome postojimo, dok naučna slika sveta boje objašnjava talasima, i time proizvodi sliku sveta boja koju je čovek konstruisao na osnovu pojavnog sveta. Realnost i istina nemaju isto značenje. Panekuk je daleko od Lenjinovog materijalističkog monizma kojemu je neprestano potrebna religija kao glavni protivnik za pobijanje, $\mathrm{i}$ koji ne može prihvatiti da je istina konstrukcija nastala na ramenima realnosti. Njegova je pozicija bliska fenomenološkoj kritici naučne slike sveta. Zato Lenjin Maha i Avenarijusa, uz sve slabosti njihovih teorija, ponajviše kritikuje tamo gde oni odstupaju od prirodno-naučnog materijalizma osamnaestog veka i gde prave razliku između realnosti i istine. Uz to Lenjin mnogo toga jednostavno ne razume ili namerno pogrešno interpretira, jer njegov jedini cilj je ubijanje opasnog virusa koji se naselio u njegovoj vlastitoj stranci. Važno je, smatra Panekuk, da se tu ne radi o lično Lenjinovom nahođenju ili sleposti, već o principu. To je najveći problem koji je Rusija morala da razreši: treba prevladati rusku zaostalost. Ruski marksizam je od samog početka ispitivao da li se može 
iz ruskih zaostalih okolnosti skočiti neposredno u komunizam, bez da bi bilo potrebno dodatno mučenje stvaranjem kapitalističke ekonomije i buržoaskog društva. Takav skok u budućnost, po definiciji avangardni čin, mogao je da bude samo skok u državni kapitalizam. Lenjinizam kao spoj buržoaskog materijalizma i marksističke doktrine društvenog razvoja začinjen dijalektičkom terminologijom postao je zvanična sovjetska državna filozofija i obavezni marksizam u celokupnoj Kominterni. Religija koju je lenjinizam pokušavao uništiti najmanje je značajna od svih savremenih ideologija, smatra Panekuk, dok su one koje najžešće pogađaju proletersku svest ideologija države i ideologija nacije. Lenjinova filozofija dostigla je stepen prosvetiteljske svesti, što je s jedne strane stavlja daleko od već tada postignutog naučnog razvoja koji je iza sebe ostavio granice galilejevsko-njutnovske slike sveta, dok je s druge strane prosvetiteljska svest udaljena od aktualnih protivrečnosti i zadataka radničkog pokreta i proleterske revolucije. Panekuku se u kritici Lenjinove i lenjinistične filozofije pridružio Karl Korš koji je iste godine objavio delo Lenjinova filozofija (Korš, 1938) i zbližio se sa komunistima saveta. ${ }^{5}$

\section{DOPISNA ŠKOLA KOMUNIZMA}

Bez obzira na gubljenje revolucionarnog zanosa, bez obzira na parlamentarni oportunizam radničkih stranaka, bez obzira na tragičnu sudbinu Sovjetskog Saveza kao ne-proleterske diktature - Panekuk je do kraja tvrdio da je kapitalizam u dubokoj krizi. Na Zapadu takozvane subjektivne snage nisu dorasle zadatku ukidanja kapitalizma u revolucionarnoj akciji. Ono što je pisao posle drugog svetskog rata polazi od procene da je radnička klasa promašila svoj istorijski cilj (Panekuk, 1946). Na tom zaključku, ipak, pravi siže ideje radničkih saveta kao novog društvenog uređenja za nove generacije (Panekuk, 1941-1947), i

\footnotetext{
${ }^{5}$ U krugu Međunarodne korespondencije saveta (1934-1953), glasila za teoriju Stranke udruženog radništva (United Workers Party), objavljivali su svoje radove Pol Matik, Karl Korš, Panekuk, Danijel Geren, Oto Rule, Viktor Serž i drugi.
} 
podvlači razliku između javnog i zajedničkog vlasništva (Panekuk, 1947). Pridružio se i pokretu naučnika za mir i protiv atomskog naoružanja. (Panekuk, 1948) Najznačajnije delo tog razdoblja jeste knjiga Radnički saveti (Panekuk, 1941-1947) koja predstavlja rezime njegovih pogleda na proletersku revoluciju, rusku revoluciju, radničke savete, ulogu političke stranke, nacizam i fašizam i posleratno doba. Delo je, kako je i sam morao priznati, prošlo nezapaženo. Najznačajniji kontakt sa novim levim pokretima uspostavio je u godinama 1953-1954. sa grupom Socijalizam ili varvarstvo dopisivanjem sa Kornelijusom Kastorijadisom. Grupa je nastala izlaskom iz trockističke Međunarodne komunističke stranke koja je nastala 1944. godine povezivanjem trockističkih grupa. Razlog za izlazak je bio da su u grupi definisali Sovjetski Savez sa njegovim posleratnim satelitima kao državni kapitalizam u kome vlast pripada novoj birokratskoj klasi, dok je trockistička dijagnoza bila da se radi o degeneraciji diktature proletarijata. U prelazu sa trockizma ka teoriji novog razreda značajnu je ulogu odigrala Đilasova knjiga Nova klasa: analiza komunističkog sistema (Đilas, 1957) Uporedo sa tim pomakom grupa je umesto komunizma u kome sve drže u rukama država i partija prihvatila komunizam saveta i time prešla na teren na kome je Panekuk bio već odranije prisutan. Čak je i razvojni put grupe bio ponavljanje već odigranog: od stranačke grupe do intelektualnog kruga, a između toga niz raspada i otpadanja, kao na primer 1963. godine kada je Kastorijadis formirao posve teoriji posvećen kružok, dok su protivnici oko ŽanFransoa Liotara hteli da nastave sa političkim delovanjem. Klod Lefor napustio je grupu već 1958. godine.

Sa Panekukom u vezu su stupili preko holandskog komuniste saveta - pripadnika grupe Spartakus Kaja Brendela. U Holandiji je deo trockističkog fronta stavove protiv Sovjetskog saveza zaoštrio već u vreme pakta Staljin - Hitler, pa pre nemačke okupacije Holandije napravio sledeći korak odvajanja od trockizma, a kada su Nemci organizaciju uništili osnovali su ilegalnu Komunističku stranku Spartakus koja je programom afirmisala izbor između socijalizma i varvarstva, da bi posle rata postala najveća internacionalno usmerena organizacija $u$ Holandiji koja je zalaganje za mir u svetu razumela kao nužnost sukoba protiv kapitalizma. Pitanje mira (začinjeno mogućnošću nuklearnog 
sukoba) bilo je centralno pitanje mnogih stranaka i grupa u svetu, a za levicu je u središtu tog pitanja bio odnos prema Sovjetskom savezu: da li treba, usprkos svemu, podržavati Sovjetski savez, a ne i ostale saveznike (stav kominternskih komunista) ili treba gajiti jednako odstojanje kako od zapadnih kapitalista tako i od sovjetskog državnog kapitalizma. Panekuk se 1944. godine penzionisao kao astronom i profesor, i nije se više uplitao u stranačke tokove i sukobe, ali je bio veliki moralni autoritet čiji je ugled prevazilazio granice pojedinih levih stranaka. Njegov uticaj, kao i ugled Gorterove tradicije i stavovi još uvek delatne Henrijete Roland Holst prouzrokovali su da se pokret opredelio za komunizam saveta. Spartakus nije u program stavio samo stranku kao izvor parlamentarnog delovanja, već i okupaciju fabrika. Okupiranje fabrika u Panekukovom rečniku je značilo tzv. ,poljske štrajkove“ koji su tako nazvani jer su poljski rudari koji nisu bili obuhvaćeni sindikalnim sistemom okupirali rudničke rovove. Kasnije se taj tip štrajkova proširio svetom pa su njime radnici izražavali istovremeno nezadovoljstvo vlasnicima, upravom i sindikalnim zastupnicima. Panekuku i ostalim holandskim spartakovcima ta vrsta „divljeg“ štrajka značila je ulazak u revolucionarni proces u slučaju da je imala i „politički značaj“, što će reći da je tražila formiranje radničkih saveta kao upravitelja procesa proizvodnje, jer je to značilo ukidanje kapitalističkog uređenja kao takvog. Međutim, Panekuk se u nekoliko značajnih tačaka razlikovao od posleratne generacije levičara. On nije verovao da je kraj drugog svetskog rata sličan završetku prvog, dakle da su okolnosti opet bremenite revolucionarnom situacijom. Tvrdio je još za vreme trajanja rata da će umesto revolucionarne situacije doći do vodeće uloge Ujedinjenih američkih država gde je radništvo daleko od bilo kakve revolucionarnosti. Za uzvrat, revolucionarno buđenje će doživeti kolonizirane zemlje, posebno u Aziji, ali će one najznačajnije, posebno Kina, krenuti putem državnog kapitalizma i zauzeti svoje mesto u redovima svetskih kapitalističkih velesila. Smatrao je da se posebno intelektualcima na Zapadu sovjetski primer toliko sviđa jer im je umesto samouprave radničkih saveta simpatičnija umerena diktatura koja je sposobna upravljati masama. (Panekuk, 1941-1947) Kajo Brandel prišao je Spartakusu 1952. godine. Holandska paralela francuskom Socijalizmu ili varvarstvu imala je u prelazu od trockizma ka komunizmu saveta 
nekoliko godina prednosti pred francuskim kolegama, tako da su onda kada su i Francuzi ušli $u$ isti proces odvajanja od trockizma brzo našli zajednički jezik. Predlog Kastorijadisu da se u ime francuske grupe obrati Panekuku kao veteranu, autoritetu klasne borbe i uglednom komunisti saveta, a pre svega izuzetnom marksističkom filozofu sa pedeset godina iskustva u strateškim i teorijskim raspravama, bio je sasvim logičan. To je dodatno utemeljeno Kastorijadisovom sve izraženijom sklonošću ka ulozi organizacije da proizvodi teoriju kao uvid u aktuelne konflikte i u alijenacijske okolnosti radničke klase. To je značilo udaljavanje od neposrednog učešća u (stranačko i parlamentarno shvaćenoj) političkoj sferi. Na tom je osnovu nastalo dopisivanje u 1953. i 1954. godini čiji je deo izašao u časopisu Socijalizam ili varvarstvo, dok je preostala korespondencija objavljena kasnije. (Castoriadis-Panekoek Exchange, 1953-1954) Prvo je Kastorijadis poslao Panekuku tadašnjih 11 brojeva časopisa, a Panekuk je objasnio da su im osnovna shvatanja jako bliska, jer i Kastorijadisovo društvo tvrdi da oslobođenje radničke klase mora biti delo same te klase, i da je stvaranje saveta početak oslobođenja preuzimanje preduzeća u upravljanje i uspostavljanje alternativnog načina upravljanja celokupnim društvom, kako bi se ukinula država sa svojim aparatima. Ali je odmah upozorio na dve tačke razmimoilaženja, i to o karakteru ruske revolucije i o ulozi partije u budućim revolucionarnim talasima. Što se ruske revolucije tiče, Panekuk je smatra buržoaskom revolucijom sličnoj svim prethodnim buržoaskim jer ju je isto ponela seljačka i radnička masa, da bi na kraju rezultati pali u ruke nekom drugom. Kastorijadis se složio da birokratija igra ulogu nove klase ne samo u Sovjetskom savezu i njemu podređenim zemljama Istočne Evrope nego i u zapadnom kapitalizmu. Ali je što se njega tiče ruska revolucija bila i proleterska revolucija jer radnički saveti inače ne bi mogli ni da se pojave - radi se o poraženoj, ali zbog toga ništa manje proleterskoj revoluciji. Što se partijskog organizovanja tiče, Panekuk je protivnik svake organizacije koja bi htela da se dočepa uloge usmeravanja revolucionarnih masa i koja bi za tu ulogu imala unapred spremna uputstva, da bi u slučaju erupcije odmah sela na rukovodeće mesto. Panekuk ostaje odlučan protivnik lenjinske partije. Njegovo poverenje pripada spontanitetu koji bi u konkretnim slučajevima otpora doveo do 
toga da se usred samih konfliktnih i kriznih situacija pojave i ljudi koji su sposobni da ih rešavaju, više nego zdravi razum ili lukavstvo uma unoseći u pokret hrabrost i odlučnost, i produbiti atmosferu kakvu je Panekuk našao u nemačkoj revoluciji posle Prvog svetskog rata. Masu pobunjenih ljudi inspiriše sudbinska međusobna povezanost i donošenje zajedničke odluke o opredeljenju oko svih kriznih, opasnih i izazovnih okolnosti, tako da svugde gde počinje revolucionarni proces nastaju i jezgra revolucionarnog osećanja koja su ujedno i izvor strategije i taktike. Ulogu tih jezgara ne može preuzeti ni jedna unapred sročena receptura skuvana u nekakvoj partiji. Kastorijadis je oko toga apsolutno suprotan. Pita se: ako nemamo ulogu pripremanja za revoluciju, za njene odluke $u$ strategiji i taktici, šta uopšte da radimo?! Pored nas, kaže, na sceni su duže od nas mnogo snažniji drugi, na primer socijalisti odnosno socijalni demokrati i komunisti koji će u slučaju osnivanja saveta odmah započeti međusobni sukob u kome će im samo jedno biti zajedničko: da mi kao male grupe ne dođemo do nikakvog izražaja. Ako se, dakle, ne postavimo kao organizacija koja hoće doći bar do reči i glasa, nećemo nikada moći započeti prosvećivanjem radništva. „Ne delovati strankom zbog toga da ne postanemo birokrate je jednako apsurdno kao što je apsurdno prestati misliti kako ne bismo pogrešili.“ (Castoriadis-Pannecoek Exchange, 1953-1954) Panekuk je odgovorio da se avangarda može roditi samo iz pokreta, nikako iz stranke koja već od ranije čeka na pokret kako bi ga uzela pod svoje. I dodaje: kapitalizam s obe strane gvozdene zavese sada je već toliko ojačao da mu se skoro niko više ne protivi. Njegova je snaga u vojničkoj spremnosti i sposobnosti nasilnog delovanja, kao i u privlačnosti ugođaja kojeg nudi otuđenje. Potreba da ga se sruši jeste veća nego ikada pre, jer se negativni učinci kapitalizma gomilaju. To sve zajedno stvara utisak bezizlaznosti kapitalizma koji je neuništiv a uništava sve oko sebe. Panekuk smatra da sve to zajedno zahteva novi način mišljenja revolucije koja više ne može biti čisto proleterska odnosno klasna. Pobuna će morati biti masovna, jer kapitalizam masovno iskorištava i ugrožava živote svih ljudi, a ne samo radničku klasu. 


\section{UMESTO ZAKLJUČKA}

Odnos Istoka i Zapada koji omogućuje Periju Andersonu da iz njega izvede koncept zapadnog marksizma nastao je u razmimoilaženjima o strategiji i taktici revolucionarnog pokreta posle Prvog svetskog rata između 1920. i 1922. godine. Ali ta priča ima rep. Od početka Druge internacionale (1889.) relativno čvrstu formu dobile su četiri različite strategije: anarhistička, liberalna, kominternska i komunistička. Liberalna, koja je odnosom prema Marksu mogla biti neortodoksna (Bernštajn) ili ortodoksna (Kautski), ostajala je unutar parlamentarnog i sindikalnog delovanja. Kominternska je čvrsto pratila svoju 21 tezu od kojih su najbitnije podređenost celine ruskoj vladajućoj ulozi i njezinim interesima, i podvlačenje rukovodeće (doslovno!) uloge komunističke partije u odnosu prema proletarijatu. Komunistička varijanta proizilazi iz radničkih saveta kao izvora moći radničke klase u revoluciji koju ne treba staviti pod nadzor nijedne druge snage ili institucije, bez obzira da li se radi o stranci, sindikatu ili državi. Demontaža državnog aparata sile nad društvom predstavlja komunističku ideju vodilju i prvu revolucionarnu meru. Anarhistička je strategija zbog zabrana i čišćenja prva postala nezavisna i izašla iz vidokruga „porodice“ koja je težila marksističkoj ortodoksiji, pa je ovde nismo ni razmatrali. Razlika između komunističkog i anarhističkog shvatanja se bitno smanjila posle pojave velikog broja novih shizmi posle Drugog svetskog rata, ali razlike nikada nisu nestale - anarhizam je ostao kriterij za određivanje granice između sukoba o ortodoksnom tumačenju Marksa i aktuelne revolucionarne situacije, i od tog sukoba nezavisnim pristupima. Objašnjavanje razlika u marksističkoj filozofiji i revolucionarnoj taktici kroz odnos između Istoka i Zapada ima težinu kakvu ima objašnjenje odnosa između anarhizma i marksističke ortodoksije kroz odnos između evropskog Juga i Severa.

Ruska je revolucija bila onoliko proleterska koliko je to bilo moguće, i ta „nečistoća“ nije neka iznimka nego karakteristika prošlih, sadašnjih i budućih revolucionarnih tokova. Bez obzira na Panekukovo objašnjenje koje proizilazi iz zaostalosti Rusije i višestruke mnogobrojnosti seljaštva u odnosu na radništvo, pokreti koji traže prevrat 
su uvek nečisti - ili ih nema i ne može biti. Kampanje čišćenja i uvođenja ,jedinonačalja“ (centralne tačke iz koje se na sve strane šalju uputstva koja traže potpuno sprovođenje bez prigovora), u kojima je Panekuk bio i svedok i žrtva, uništavaju ono što je Panekuku najznačajnije: da se razlike susreću u revolucionarnoj situaciji, u atmosferi masovnog nezadovoljstva, pobune i ustanka kada u takvim pregrejanim okolnostima treba suočiti poglede i prihvatiti zajedničko presuđivanje pobunjene mase. Do toga može doći jedino u slučaju da su različite strategije i taktike sposobne ostati zajedno odnosno izraziti svoje razlike u zajedničkom prostoru presuđivanja, i to ne kao disput različitih škola mišljenja u akademskom okruženju nego pred masovnom pobunjenom publikom. Takva su stvarno i bila suočavanja različitih predloga za nastavljanje pokreta u godinama 1918 - 1921. ispred „parlamenta“ radničkih saveta, sve dok revolucije u Nemačkoj, Mađarskoj i drugde nisu bile poražene upotrebom državnog nasilja, a sovjetska je ispala pobednica. U trenutku kada se pobeda nad protivnicima $u$ građanskom ratu i stranim intervencionistima mogla proglasiti zajedno sa proglasom poraza revolucije na Zapadu, radnički saveti i njihovi delegati sve do vrha Sovjetskog Saveza predali su svoju moć u ruke Države i Partije. Ko se tome nije povinovao bio je dvaput poražen - kao akter revolucije koja se predala, i kao zagovornik komunizma radničkih saveta. Tu je mesto Panekuku.

\section{LITERATURA}

\section{Dela Antonija Panekuka}

1902 The Position and Significance of J. Dietzgen's Philosophical Works, dostupno na: https://www.marxists.org/archive/pannekoe/1902/ dietzgen.htm (provereno 1.3.2020.).

1910 Marksizam i darvinizam, s prilogom: Borba za opstanak (G. Ekštajn), Požarevac, Štamparija Đorđa Naumovića (prvi engleski prevod 1912, knjiga napisana 1909).

1912a Marxist Theory and Revolutionary Tactics, dostupno na: https://www.marxists.org/archive/pannekoe/1912/tactics.htm (provereno 1.3.2020).

1912b Class Struggle and Nation, dostupno na: https://www.marxists.org/ archive/pannekoe/1912/nation.htm (provereno 1.3.2020). 
1912c Massenaktion und Revolution, Die neue Zeit, Stuttgart.

1913 War Against War, dostupno na: https://www.marxists.org/archive/ pannekoe/1913/02/waw.html (provereno 1.3.2020).

1917a After the War Ends, dostupno na: https://www.marxists.org/archive/ pannekoe/1917/after-war-ends.htm (provereno 1.3.2020)

1917b The Third International, dostupno na: https://www.marxists.org/archive/ pannekoe/1917/thirdinter.htm (provereno 1.3.2020).

1920 World Revolution and Communist Tactics, dostupno na: https://www.marxists.org/archive/pannekoe/1920/communisttactics.htm (provereno 1.3.2020).

1938 Lenin As Philosopher, dostupno na: https://www.marxists.org/ archive/pannekoe/1938/lenin/index.htm (provereno 1.3.2020).

1946 The Failure of the Working Class, dostupno na: https://www.marxists.org/ archive/pannekoe/1946/failure-working-class.htm (provereno 1.3.2020).

1941-1947 Workers' Councils, dostupno na: https://www.marxists.org/archive/ pannekoe/1947/workers-councils.htm (provereno 1.3.2020).

1947 Public Ownership and Common Ownership, dostupno na: https://www.marxist.org/archive/pannekoe/1947/public-ownership.htp (provefreno 1.3.2020).

1948 Revolt of the Scientists, dostupno na: https://www.marxists.org/ archive/pannekoe/1948/revolt.htm (provereno 1.3.2020).

1953-1954 The Castoriadis-Pannekoek Exchange, dostupno na: https://www.viewpointmag.com/2011/10/25/deviations (provereno 1.3.2020).

1961 A History of Astronomy, New York, Interscience Publishers, dostupno na: https://1lib.3eu/book/3411059/13e50c?regionChanged (provereno 1.3.2020).

\section{Druga navedena dela}

Andersson, Perry, 1985, Razmatranja o zapadnom marksizmu, Beograd: BIGZ.

Bellamy, Edward, 1903, U godini 2000: osvrt na godinu 1887, Zagreb: L. Hartman.

Bellamy, Edward, 2007, Equality, dostupno na: https://www.amazon.de/ Equality-Edward-Bellamy-2007-10-11/dp/B01K95S1NS (provereno 1.3.2020; prvo izdanje 1897).

Bernstein, Edward, 1993, The Preconditions of Socialism, (Cambridge Texts in the History of Political Thought) (H. Tudor, Ed.), Cambridge: Cambridge University Press. 
Dietzgen, Joseph, 1958, Odabrani filozofski radovi, Zagreb, Naprijed.

Đilas, Milovan, 1990, Nova klasa, Beograd, Narodna knjiga.

Istorija svesavezne komunističke stranke (boljševika): kratki kurs (ISKPb), 1947, Beograd: Kultura.

Korsch, Karl, 1938, „Lenin as Philosopher“, Living Marxism, 4, 5, 138-144, dostupno na https://www.marxist.org/korsch/1938/lenin-philosophy.htm (provereno 1.3.2020)

Lenjin, Vladimir Iljič, 1974, Materijalizam i empiriokriticizam: Kritičke primedbe o jednoj reakcionarnoj filozofiji, u: Lenjin, Vladimir Iljič, Dela tom 14, Beograd, Yugoslavia public, 55-312.

Lenjin, Vladimir Iljič, 1975, Država i revolucija: Učenje marksizma o državi i zadaci proletarijata u revoluciji, u: Lenjin, Vladimir Iljič, Dela tom 26, Beograd, Yugoslavia public, 133-219.

Lenjin, Vladimir Iljič, 1976, Dečja bolest „levičarstva“ " u komunizmu, u: Lenjin, Vladimir Iljič, Dela tom 32, Beograd, Yugoslavia public, 133-204.

Lukač, Đerđ, 1967, History and Class Consciousness, Londo, Merlin Press, novi predgovor iz 1967. godine dostupan na: https://www.marxist.org/archive/lukacs/works/history/lukacs1967.htm (provereno 1.3.2020).

Lukač, Đerđ, 1970, Povijest i klasna svijest: studija o marksističkoj dijalektici, Zagreb: Naprijed.

\title{
LEV KREFT
}

University of Ljubljana, Faculty of Arts, Slovenia

\section{HOW PANNEKOEK BECAME APOSTATE THREE TIMES}

\begin{abstract}
The purpose of research was to study Anton Pannekoek's activity and his writings as a source of information on his movement across the history of revolutionary movement and Marxist theory. In this paper, this movement is reduced to three schisms: between revisionism and orthodoxy, between reformism and revolution, and between state communism and council communism. Here, we left out the first schism between anarchism and Marx(ism) because anarchists were the first to be excluded and therefore not discussed thoroughly by Pannekoek. The last schism, that between state communism and council communism, is a missing link of division on Western
\end{abstract}


and Eastern Marxism which originates in conflict on strategy and tactics within the Communist International (1920-1922) when, finally, Lenin's strategic and tactical line established in 'Left-Wing' Communism: An Infantile Disorder against all those who were opposing parliamentary and trade-unionist strategy as the only communist revolutionary engagement. Pannekoek was fighting against this solution throughout his later theoretical and activist life. He reached the highest point of comprehension possible from his point of view in his books Lenin as Philosopher (1938) and Workers Councils (1941-1947). Finally, when he got in touch with Socialism or Barbarity group of Cornelius Castoriadis and Claude Lefort in 1953, he explained himself to the new generation of revolutionaries and Marxist theoreticians in correspondence with Cornelius Castoriadis. The conflict and its schismatic consequences are far from over yet. In our epoch characterized from different points of view as transition to postcapitalism it emerges again, this time on global scale.

Keywords: Anton Pannekoek, Western Marxism, workers' councils, new class, Lenin's vulgar materialism

Primljeno: 1.3.2020.

Prihvaćeno: 6.5.2020. 